\title{
Why is Acartia tonsa (Copepoda: Calanoida) restricted to nearshore environments?
}

\author{
Gustav-Adolf Paffenhöfer ${ }^{1}$, Donald E. Stearns ${ }^{2}$ \\ 'Skidaway Institute of Oceanography, PO Box 13687, Savannah, Georgia 31416, USA \\ ${ }^{2}$ Dauphin Island Sea Lab., PO Box 369-370, Dauphin Island, Alabama 36528, USA
}

\begin{abstract}
The copepod Acartia tonsa is adapted to high food concentrations which it encounters in estuaries and upwelled waters. It cannot obtain sufficient food for reproduction on the middle and outer shelf, where food concentrations are usually low, because it decreases clearance rates when concentrations of Thalassiosira weissflogi fall below $0.25 \mathrm{~mm}^{3} 1^{-1}$ In comparison, the offshore copepod Paracalanus sp. continues to increase its clearance rate when food levels are below the abovementioned concentration. Several factors are thought to be responsible for this reduction of clearance rates of $A$. tonsa feeding on T. weissflogii: (1) The proportion of time during which water is transported towards the copepod decreases with decreasing food concentration. (2) The efficiency of capturing food particles decreases below $22 \mu \mathrm{g} \mathrm{Cl}^{-1}\left(=0.28 \mathrm{~mm}^{3} \mathrm{l}^{-1}\right.$ of $T$. weissflogi $)$. (3) A. tonsa does not seem to reroute phytoplankton cells individually towards its median, and therefore cannot use a, hypothesized, increased sensitivity of its chemoreceptors at low chlorophyll concentrations to increase clearance rate.
\end{abstract}

\section{INTRODUCTION}

The genus Acartia (Copepoda: Calanoida) occurs mostly in estuaries and nearshore environments although several representatives of the genus are found offshore (i.e. A. danae, A. negligens; Bowman 1971). A. tonsa is found throughout the year in the estuaries of Georgia and South Carolina, USA, when water temperatures range from 9 to $30^{\circ} \mathrm{C}$ (Lonsdale \& Coull 1977, Paffenhöfer unpubl.). In terms of biomass it is the most abundant zooplankton species in the estuaries of North and South Carolina (Lonsdale \& Coull 1977, Fulton 1984). It is the most frequently occurring zooplankton species in Georgia estuaries (Jacobs 1968, Stickney \& Knowles 1975). However, A. tonsa is rarely abundant ( $>100$ ind $\mathrm{m}^{-3}$ ) on the middle and outer shelf (Paffenhöfer unpubl.). There, throughout most of the year, representatives of the genus Paracalanus are among the most abundant copepods. In estuaries, their close relative Parvocalanus crassirostris is often as abundant as A. tonsa (Lonsdale \& Coull 1977).

Why is Acartia tonsa abundant in estuaries but not on the shelf? In order to answer this question, we considered 4 variables: temperature, salinity, predation and food. Temperature is not considered a limiting factor since it is higher during winter and slightly lower during summer on the sheif than in the estuaries. Thus, A. tonsa would experience less temperature stress offshore than in the estuary. Also, $A$. tonsa is able to adapt to temperatures ranging from -1 to $32^{\circ} \mathrm{C}$ (Gonzalez 1974). Neither is salinity limiting: at $17^{\circ} \mathrm{C}, A$. tonsa females survived about equally well at salinities ranging from 11 to $36 \%$ (Lance 1964). Predation does not appear to be the decisive variable in restricting $A$. tonsa offshore distribution, since the species maintains its high abundance near- and inshore, partly because of its superior ability (as compared to Paracalanus and others) to avoid predation by planktivorous fish (Kimmerer 1986, for A. tranteri). This leaves only food with all the components of animal-algae interactions as a possible controlling variable.

Size, quantity and quality of available food affect survival, growth, and reproduction of calanoid copepods (e.g. Paffenhöfer 1970, Checkley 1980, Durbin et al. 1983, Ambler 1985, 1986). When food intake by adult females of Paracalanus parvus, which occur in shelf waters, and Acartia tonsa was compared using similar mixtures of phytoplankton, A. tonsa was not able to feed on the smallest particles ingested by P. parvus (Bartram 1981). When both copepods were offered mixtures of diatoms and small flagellates, the 
feeding rate of $P$. parvus was higher than that of A. tonsa. When the naturai phytoplankton included motile dinoflagellates, overall ingestion rates were not significantly different (Bartram 1981). Little was said by Bartram about the concentrations at which the different cell sizes were offered. Since $A$. tonsa is abundant-todominant only in regions of high particle concentration and ceases to feed when chlorophyll a concentrations decrease to about $1 \mu \mathrm{g} \mathrm{l}^{-1}$ (Reeve \& Walter 1977) we decided to determine clearance rates of both $A$. tonsa and Paracalanus sp. and to compare their feeding behavior at phytoplankton concentrations in the range of values typical of middle shelf areas and estuaries. Nearshore and middle-shelf chlorophyll a concentrations range annually from ca 2 to 8 and 0.1 to $2 \mu \mathrm{g}$ $1^{-1}$, respectively (Bishop et al. 1980). The latter was on average near $0.5 \mu \mathrm{g} \mathrm{l}^{-1}$ which amounts to $0.2 \mathrm{~mm}^{3} \mathrm{l}^{-1}$ of exponentially growing Thalassiosira weissflogii (Paffenhöfer unpubl.).

\section{MATERIALS AND METHODS}

All laboratory experiments were conducted at $20^{\circ} \mathrm{C}$ for periods of 20 to $24 \mathrm{~h}$ using a light/dark cycle of 14/ $10 \mathrm{~h}$. Six to 12 females of Acartia tonsa or Paracalanus sp., preconditioned to respective experimental food concentration for about $2 \mathrm{~d}$, were placed in $960 \mathrm{ml}$ or $1900 \mathrm{ml}$ jars rotated at about $0.5 \mathrm{rpm}$ on a Ferris wheel. We chose the diatom Thalassiosira weissflogii (12 to $15 \mu \mathrm{m}$ diameter) as food since it is typical of size, shape and type of phytoplankton representatives dominant in estuarine and coastal waters (Riley 1967, Raymont 1980, Bishop et al. 1980). Salinity was $35 \%$ and phytoplankton nutrients were added to ail experimental and control jars resulting in a nitrate concentration of $2 \mu \mathrm{M}$. Clearance rates were determined by counting cells under an inverted microscope, in samples taken at the start and end of each experiment. The equations of Frost (1972) were used to calculate average food concentrations and clearance rates. We rarely observed mortality during our experiments and used only the number of surviving copepods in feeding-rate calculations if one copepod had died.

High-speed cine films of feeding behavior were made as decribed by Price et al. (1983). All movies of Paracalanus sp. were made at 500, of Acartia tonsa at 250 and 500 frames $s^{-1}$. Copepods used for filming were females which had a cat hair glued to their cephalothorax to keep them in position during filming. Exceptions were several $A$. tonsa females which were filmed free-swimming (without being attached to a hair). The objective of filming $A$. tonsa was to determine how it gathers and ingests phytoplankton cells. We did not quantify particle ingestion from movies because $A$. tonsa feeding rates are strongly affected by light (Stearns 1986).

\section{RESULTS}

We calculated geometric means of clearance rates for various ranges of average food concentrations because the distribution of clearance rates were log normal: for Acartia tonsa these ranges were 0.1 to $0.2,0.2$ to $0.3,0.3$ to 0.45 and 0.8 to $1.35 \mathrm{~mm}^{3} \mathrm{l}^{-1}$; for Paracalanus sp., 0.05 to $0.2,0.2$ to 0.35 and 0.8 to $1.1 \mathrm{~mm}^{3} \mathrm{l}^{-1}$ (Fig. 1).

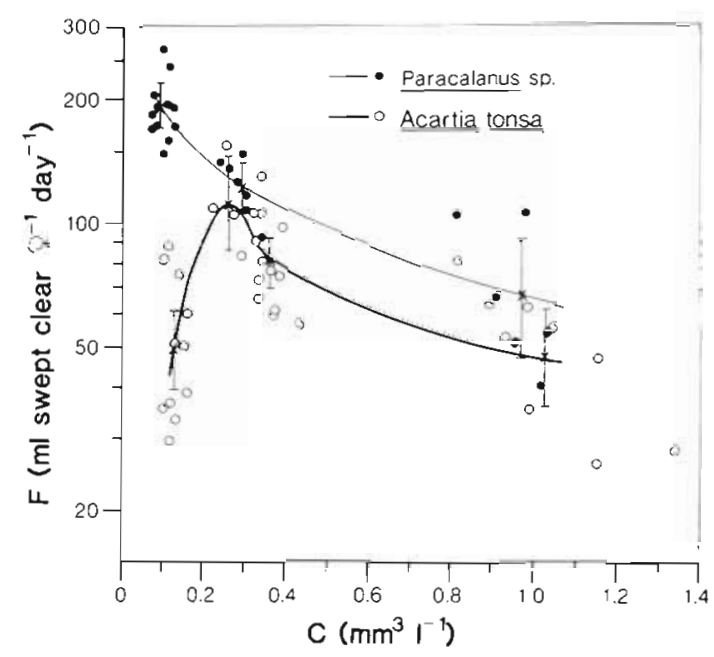

Fig. 1. Paracalanus sp. and Acartia tonsa. Clearance rate $(F)$ of adult females feeding on the diatom Thalassiosira weissflogii. Clearance rates of Paracalanus sp. are the geometric means of the following ranges of food concentration: 0.05 to $0.20,0.20$ to $0.35,0.80$ to $1.10 \mathrm{mml}^{3} \mathrm{l}^{-1}$. For A. tonsa geometric means were calculated for the following ranges: 0.05 to $0.20,0.20$ to 0.30 , 0.30 to $0.45,0.80$ to $1.40 \mathrm{~mm}^{3} \mathrm{l}^{-1}$ Bars: $95 \%$ confidence limits. Lines drawn by hand

Clearance rates of $A$. tonsa increased as the food concentrations decreased to about 0.2 to $0.3 \mathrm{~mm}^{3} \mathrm{l}^{-1}$ of Thalassiosira weissflogii. Below that concentration clearance rates dropped sharply. In contrast, clearance rates of Paracalanus $\mathrm{sp}$. increased monotonically to as low as $0.05 \mathrm{~mm}^{3} \mathrm{l}^{-1}$ (Fig. 1). Near $0.1 \mathrm{~mm}^{3} \mathrm{l}^{-1}$, A. tonsa ingested only about $26 \%$ of what Paracalanus consumed whereas at $0.3 \mathrm{~mm}^{3} \mathrm{l}^{-1}$, ingestion rates hardly differed.

Since we thought that visual observations could help interpret our findings, several films of Paracalanus sp. were made at 1.0 and $3.0 \mathrm{~mm}^{3} \mathrm{l}^{-1}$ of Thalassiosira weissflogii, and of Acartia tonsa at 2.0 and $2.9 \mathrm{~mm}^{3} \mathrm{l}^{-1}$ of the same algae and at a mixture of $0.5 \mathrm{~mm}^{3} \mathrm{l}^{-1}$ of $T$. weissflogii and $6.0 \mathrm{~mm}^{3} \mathrm{l}^{-1}$ Rhizosolenia alata. We did not film at low food concentrations because of the small probability of encountering a cell at 0.2 to 0.3 $\mathrm{mm}^{3} \mathrm{l}^{-1}$ during $8 \mathrm{~s}$ of filming. Paracalanus creates a 
feeding current with its second antennae (A2), first maxillae (M1) and maxillipeds (MXP). It uses its MXP and $A 2$ to direct oncoming $T$. weissflogii to its median (chopstick motion = flicks; Alcaraz et al. 1980). The second maxillae (M2) fling open and capture the cell, which is then directed towards the mouth by the endites of $M 1$ (see also Price et al. 1983). Paracalanus moves its mouthparts (excluding M2) almost continuously. According to Price \& Paffenhöfer (1986) it spends up to $80 \%$ of the time moving its mouthparts.

Acartia tonsa like $A$. clausi creates a feeding current mainly with its A2, M2 and thoracopods (Rosenberg 1980). Motions of all mouthparts are intermittent because this species takes frequent breaks. We did not observe flicks by any individual mouthparts, as observed for Paracalanus and other calanoids (Price et al. 1983). Whereas the M2 of $A$. tonsa are larger and its distal M2 setae are about 3 times longer than those of Paracalanus (Fig. $2 \& 3$ ), the MXP of $A$. tonsa are tiny (see also Schnack 1982) and cannot perform the chopstick function of Paracalanus MXP. While Paracalanus usually responded individually to single cells by flicking motions mostly of $\mathrm{A} 2$ or MXP, A. tonsa did not. Even offering a large diatom (Rhizosolenia alata, $28 \mu \mathrm{m}$ width, 200 to $350 \mu \mathrm{m}$ length) did not result in motions of individual mouthparts of $A$. tonsa. We also observed cleaning motions and occasionally rejections of cells after $A$. tonsa had brought them to their mouth. On rare occasions we noticed a wider-than-usual opening of

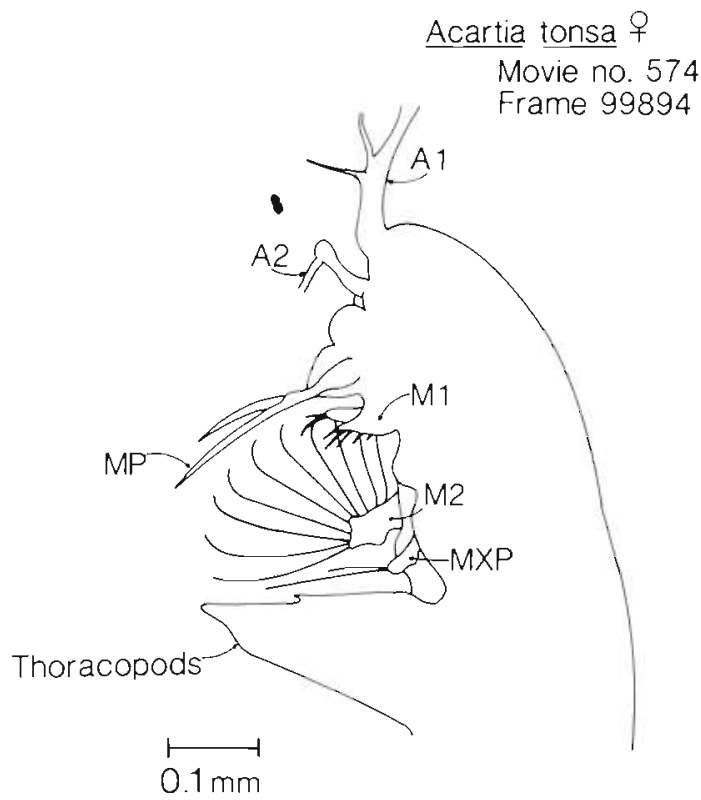

Fig. 2. Acartia tonsa. Female mouthparts. Lateral view. First (A1) and second (A2) antennae only partly shown; second maxillae (M2) in open position; M1: endites of first maxillae; MP: mandibular palps; MXP: maxilliped; a chain of 2

Thalassiosira weissflogii cells is shown near A.1 and A2

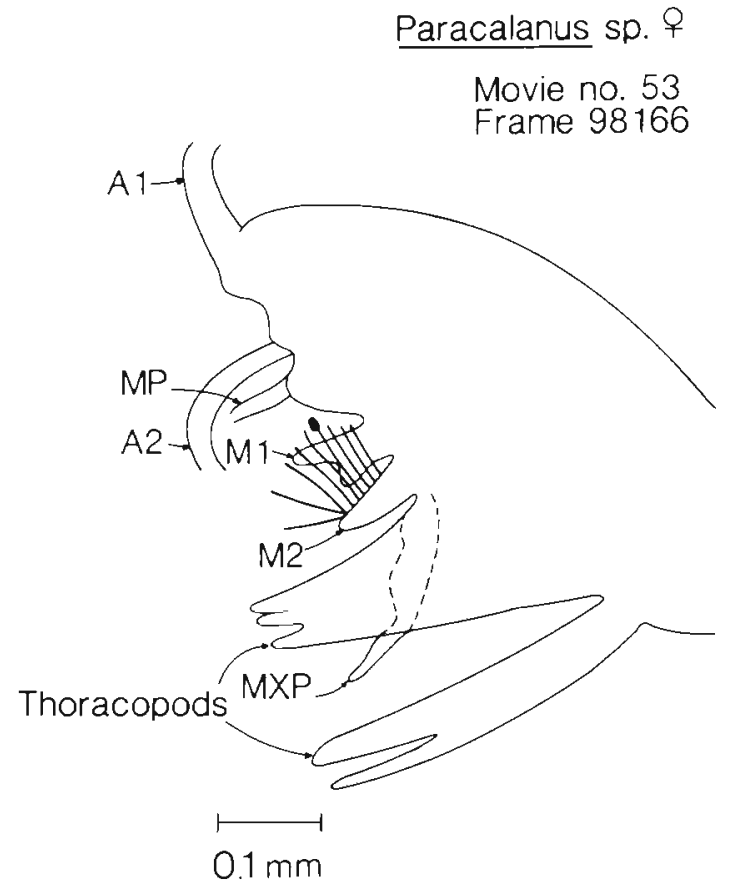

Fig. 3. Paracalanus sp. Female mouthparts. Lateral view. A1, A2 and MP only partly shown; M2 slightly opened; M1 out of focus; setae on MXP not drawn because they were out of focus; 1 Thalassiosira weissflogi cell shown near M1

the M2 and, separately, weak independent motions of one of the A2 and mandibular palps (MP).

\section{DISCUSSION}

Comparison of clearance rates of females of Acartia tonsa and Paracalanus sp. shows that the former is not adapted to the low food concentrations $\left(<0.25 \mathrm{~mm}^{3} \mathrm{l}^{-1}\right.$ of particulate matter) encountered on the southeastern continental shelf during much of the year (Bishop et al. 1980). At $0.1 \mathrm{~mm}^{3} \mathrm{l}^{-1}$ of Thalassiosira weissflogii, an adult $A$, tonsa female ingested 0.5 , and an adult Paracalanus sp. female $1.9 \times 10^{7} \mu^{3}$ of $T$. weissflogii in $24 \mathrm{~h}$. These values amount to 0.40 and $1.52 \mu \mathrm{g}$ of organic carbon, respectively. Subtracting metabolic costs (calculated from Kiørboe et al. 1985), A. tonsa assimilated sufficient energy to produce about 2 eggs $\mathrm{d}^{-1}$. Paracalanus sp; at the same food concentration would produce 24 eggs $\mathrm{d}^{-1}$ (Checkley 1980, his Fig. 6). This comparison shows that it is unlikely that $A$. tonsa can maintain a population on the shelf over longer periods when feeding mainly on phytoplankton.

Why could Acartia tonsa not obtain large amounts of food at low phytoplankton concentrations compared to the offshore copepods Paracalanus sp. and Eucalanus pileatus, which maintained high clearance rates at food concentrations below $0.1 \mathrm{~mm}^{3} \mathrm{l}^{-1}$ of phytoplankton 
cells $>12 \mu \mathrm{m}$ width (Paffenhöer 1984). Near $0.3 \mathrm{~mm}^{3}$ $1^{-1}$ of Thalassiosira weissflogii, $A$. tonsa reached a threshold concentration below which the clearance rate decreased. Such decreases have been observed previously also in A. tonsa (Kiørboe et al. 1985), Calanus helgolandicus (Corner et al. 1972), Calanus pacificus (Frost 1975), and Eucalanus elongatus (Price \& Paffenhöfer 1986). The reduction in clearance rate of E. elongatus was related to a reduction in the percentage of time when this copepod was creating a feeding current. This was interpreted as an adaptation to conserve energy when food concentrations are low. Similarly, A. clausi, feeding on the dinoflagellate Gyrodinium fissum (ca $34000 \mathrm{\mu m}^{3}$ cell volume) reduced the frequency of mouthpart movements (creating a feeding current) with decreasing food concentrations (Table 1; Piontkovskii \& Petipa 1976). This behavior and changes in the efficiency of feeding (Table 1)

Table 1 Acartia clausi. Mouthpart movement frequency and efficiency of food capture by females at 20 to $22^{\circ} \mathrm{C}$ in relation to food concentration (data from Piontkovskii \& Petipa 1976)

\begin{tabular}{|c|c|c|c|c|}
\hline \multicolumn{5}{|l|}{ Food concentration } \\
\hline Cells ml $\mathrm{ml}^{-1}$ & 0.05 & 0.5 & 5 & 15 \\
\hline$m m^{3} 1^{-1}$ & 0.0017 & 0.017 & 0.17 & $0.51^{\circ}$ \\
\hline $\mathrm{ca} \mu \mathrm{gC} 1^{-1}$ & 0.2 & 2 & 22 & $66^{\circ}$ \\
\hline $\begin{array}{l}\text { Number of mouthpart } \\
\text { grasping movements } \\
\text { per min }\end{array}$ & 4 & 13 & 34 & 49 \\
\hline $\begin{array}{l}\text { Efficiency of capture } \\
\text { (=\% of encountered algal } \\
\text { cells captured })\end{array}$ & 16 & 22 & 26 & 16 \\
\hline \multicolumn{5}{|c|}{$\begin{array}{l}\text { For comparison food concentration expressed as } \mathrm{mm}^{3} \mathrm{l}^{-1} \\
\left(1 \text { cell } \sim 34000 \mu \mathrm{m}^{3}\right) \text { and } \mu \mathrm{gCl} \mathrm{l}^{-1}\left(1 \mathrm{~mm}^{3} \text { of }\right.\end{array}$} \\
\hline
\end{tabular}

indicate an increase in clearance rate when food concentration is lowered from 66 to $22 \mu \mathrm{gC} \mathrm{l}^{-1}$; this is

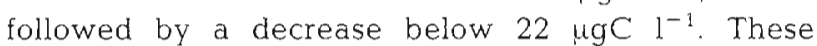
changes in behavior and efficiency agree with our observations of changing clearance rate in $A$. tonsa (Fig. 1).

What causes Eucalanus pileatus and Paracalanus sp. to increase clearance rates at low food concentrations, and why is Acartia tonsa not able to do the same? Our limited data on feeding behavior indicate that $E$. pileatus and Paracalanus sp., in contrast to A. clausi, do not greatly reduce the proportions of time creating feeding currents when food concentrations decrease from 3.0 to $0.3 \mathrm{~mm}^{3} \mathrm{l}^{-1}$ of Thalassiosira weissflogii. All 3 copepods create feeding currents to move water con- taining food particles towards themselves. While Paracalanus sp. and E. pileatus create these currents by motions of their A2, M1 (exopodites) and MXP (Strickler 1984), $A$. tonsa does this by motions of its A2, M2 and thoracopods. Paracalanus sp. and E. pileatus collect algae by altering the flow direction of part of the current towards the copepod's median with flicks of individual mouthparts. Each flick is thought to be elicited by chemical exudates which, through accelerated flow of the feeding current, precede a phytoplankton cell and provide signals to chemoreceptors on A1 and other mouthparts (Andrews 1983). MXP and A2 are the mouthparts which most frequently aid in gathering food particles. They extend farthest from the copepod's body and therefore can re-route (Strickler 1985) phytoplankton cells in a wide range of distances from the copepod's body. For marine invertebrates, natural stimulus intensities for chemoreceptors range over at least 6 orders of magnitude (Atema 1985). Thresholds of releasing stimuli are lowered with increasing periods of quiescence (Lorenz 1981). Assuming that signal strength and quality of a phytoplankton cell does not change with changes in food concentration, we hypothesize that, with decreasing food concentrations, the range and distance at which phytoplankton cells can be detected by Paracalanus sp. and E. pileatus increases. This would result in the observed increase in clearance rate. M2 of Paracalanus are small and setae short relative to its cephalothorax (Fig. 3). The function of $\mathrm{M} 2$ is to capture a particle of water containing phytoplankton and to transfer it to the endites of the M1.

In Acartia tonsa MXP are tiny and their function is unknown (Fig. 2). Food collection and capture seem to be conducted only by one pair of mouthparts, the M2. These capture parcels of water which are larger than those captured by the M2 of Paracalanus sp., and displace the parcels with their particle contents towards the copepod. The particle-capturing ability of M2 in $A$. tonsa may be enhanced by the inwardly curved tips of the setae. It appears that $A$. tonsa is not able to sense individual cells displaced towards it, or to change the flow field as do the above-mentioned copepods. Not being able to re-route oncoming cells implies that $A$. tonsa cannot use the increased sensitivity of its A1, or of other chemoreceptors, at low phytoplankton concentrations for capturing cells outside its (narrow) motion core (Strickler 1985). Paracalanus sp. and Eucalanus pileatus, however, can sense and reroute cells in the (wider) sensory core (Strickler 1985) and thereby obtain more food than $A$. tonsa when food levels are below $0.25 \mathrm{~mm}^{3} 1^{-1}$ of Thalassiosira weissflogii. In sensing chemical signals, Acartiidae are at a disadvantage since they have fewer chemoreceptors on their first antennae (A1) than other copepods, including 
Calanus finmarchicus and Centropages furcatus (Barrientos Chacon 1980).

A pronounced ability of the Acartiidae to sense hydrodynamic signals is indicated by observations of Barrientos Chacon (1980) who found that e-type sensory hairs (mechanoreceptors) are more numerous on the Al of the 3 species of Acartia than on other species. This, and the rapid opening and closing of its large M2 ( 8 to $16 \mathrm{~ms}$ ) and thoracopods which transport much water swiftly towards the copepod, could represent the adaptation of $A$. tonsa to carnivory. The rapid displacement of water is too fast to be overcome by escape moves of nearby prey. The short intermittent periods of mouthpart activity of $A$. tonsa, especially when food is scarce (Piontkovskii \& Petipa 1976), are another indicator of carnivory because - during periods of rest (slow sinking) - few hydrodynamic signals are given to nearby prey.

From the above one may assume that Acartia tonsa could maintain a population offshore through carnivory. On the middle and southeastern continental shelf concentrations of nauplii in excess of $20 \mathrm{l}^{-1}$ are found only in, or above, older upwelled water masses (Paffenhöfer et al. 1984). At a clearance rate of $100 \mathrm{ml}$ copepod $\mathrm{d}^{-1} \mathrm{~d}^{-1}$, A. tonsa would obtain an additional 0.1 to $0.2 \mu \mathrm{gC}$ at 20 nauplii $l^{-1}$. This would only slightly increase its reproductive rate. Ciliates do not appear to constitute a major food source because their concentration on the inner to outer southeastern continental shelf was low, ranging from 0.1 to $2.1 \mu \mathrm{gC} \mathrm{l}^{-1}$ (Sherr et al. 1986).

Availability or concentration of food could have been important environmental variables that, through evolution, selected for different ways to gather food by various copepod taxa, which then led to the observed nearto offshore copepod distributions. The behavioral capacity of copepods to respond to high, low and varying food regimes by feeding sufficiently for survival and reproduction seems to determine near- to offshore changes in zooplankton community composition.

It appears that a combination of factors contribute to the inability of Acartia tonsa to obtain sufficient amounts of food for reproduction when food concentrations are below $0.2 \mathrm{~mm}^{3} \mathrm{l}^{-1}$ of Thalassiosira weissflogii. Future studies under conditions of low light intensity should verify whether $A$. tonsa behaves similarly to $A$. clausi with respect to the frequency of feeding motions and efficiency of food captured at decreasing food concentrations. We also need to determine whether the inability of $A$. tonsa to re-route $T$. weissflogii particles at concentrations above $2 \mathrm{~mm}^{3} \mathrm{l}^{-1}$ pertains also to lower food concentrations. While $A$. tonsa cannot maintain a population in offshore waters, A. danae, which reaches concentrations $>300$ copepods $\mathrm{m}^{-3}$ (Paffenhöfer unpubl.) and A. negligens are able to do that. Comparing their feeding behavior with that of $A$. tonsa will be one of the next steps toward a better global understanding of copepod distribution and presence in the ocean.

Acknowledgements. This research was supported by National Science Foundation Grant OCE85-00917 and Department of Energy Grant DE-FG09-85ER60354-A001 Kellie Lewis conducted part of the feeding experments, Dannah McCauley typed the manuscript, and Anna Boyette drew the graphs. Drs E. G. Durbin, D. W. Menzel, H. J. Price, J. R. Strickler and H. A. Vanderploeg critically evaluated an earlier version of this manuscript. We thank them for their support and advice.

\section{LITERATURE CITED}

Alcaraz, M., Paffenhöfer, G.-A., Strickler, J. R. (1980). Catching the algae: a first account of visual observations on filter feeding calanoids. In: Kerfoot, W. C. (ed.) The evolution and ecology of zooplankton communities. Univ. Press of New England, p. 241-248

Ambler, J. W. (1985). Seasonal factors affecting egg production and viability of eggs of Acartia tonsa Dana from East Lagoon, Galveston, Texas. Estuar coast. Shelf Sci. 20: $743-760$

Ambler, J. W. (1986). Effect of food quantity and quality on egg production of Acartia tonsa Dana from East Lagoon, Galveston, Texas. Estuar. coast. Shelf Sci. 23: 183-196

Andrews, J. C. (1983). Deformation of the active space in the low Reynolds number feeding current of calanoid copepods. Can. J. Fish. aquat. Sci. 40: 1293-1302

Atema, J. (1985). Chemoreception in the sea: adaptations of chemoreceptors and behavior to aquatic stimulus conditions. In: Laverack, M. S. (ed.) Physiological adaptations of marine animals. Symp. Soc. Exp. Biol. No. 39. The Company of Biologists Limited, Cambridge, p. 387-423

Barrientos Chacon, Y (1980). Ultrastructure of sensory units of the first antennae of calanoid copepods. M. Sc. thesis, University of Ottawa, Ontario, Canada

Bartram, W C. (1981). Experimental development of a model for the feeding of neritic copepods on phytoplankton. J. Plankton Res. 3: 25-51

Bishop, S. S., Yoder, J. A., Paffenhöfer, G.-A. (1980). Phytoplankton and nutrient variability along a cross-shelf transect off Savannah, Georgia, U.S.A. Estuar. coast. mar. Sci. 11: 359-368

Bowman, T. E. (1971). The distribution of calanoid copepods off the southeastern United States between Cape Hatteras and southern Florida. Smithson. Contrib. Zool. 96: 1-58 (Smithsonian Institution Press, Washington, D.C.)

Checkley, D. M., Jr. (1980). The egg production of a marine planktonic copepod in relation to its food supply; laboratory studies. Limnol. Oceanogr. 25: 430-446

Corner, E. D. S., Head, R. N., Kilvington, C. C. (1972). On the nutrition and metabolism of zooplankton. VIII. The grazing of Biddulphia cells by Calanus helgolandicus. J. mar. biol. Ass. U.K. 52: 847-861

Durbin, E. G., Durbin, A. G., Smayda, T. J., Verity, P. G. (1983). Food limitation of production by adult Acartia tonsa in Narragansett Bay, Rhode Island. Limnol. Oceanogr 28: 1199-1213

Frost, B. W (1972). Effects of size and concentration of food particles on the feeding behavior of the marine planktonic copepod Calanus pacificus. Limnol. Oceanogr 17 $805-815$ 
Frost, B. W. (1975). A threshold feeding behavior in Calanus pacificus. Limnol. Oceanogr 20: 263-266

Fulton, R. S., III. (1984). Distribution and community structure of estuarine copepods. Estuaries 7. 38-50

Gonzalez, J. G. (1974). Critical thermal maxima and upper lethal temperatures for the calanoid copepods Acartia tonsa and A. clausi. Mar. Biol. 27: 219-223

Jacobs, J. (1968). Animal behavior and water movement as codeterminants of plankton distribution in a tidal system. Sarsia 34: 355-370

Kimmerer, W. J. (1986). The paradox of plankton reversed: what limits the diversity of inshore marine zooplankton? AGU/ASLO-Meeting, San Francisco, 8-12 Dec. 1986

Kiørboe, T., Mohlenberg, F., Hamburger, K. (1985) Bioenergetics of the planktonic copepod Acartia tonsa: relation between feeding, egg production and respiration and composition of specific dynamic action. Mar. Ecol Prog. Ser. 26: 85-97

Lance, J. (1964). The salinity tolerances of some estuarine crustaceans. Biol. Bull. mar. biol. Lab., Woods Hole 127 : $108-118$

Lonsdale, D. J., Coull, B. C. (1977). Composition and seasonality of zooplankton of North Inlet, South Carolina Chesapeake Sci. 18: 272-283

Lorenz, K. Z. (1981). The foundations of ethology. SpringerVerlag, New York

Paffenhöfer, G.-A. (1970). Cultivation of Calanus helgolandicus under controlled conditions. Helgoländer wiss. Meeresunters. 20: 346-359

Paffenhöfer, G.-A. (1984). Calanoid copepod feeding: Grazing on small and large particles. In: Meyers, D. G., Strickler, J. R. (ed.) Trophic interactions within aquatic ecosystems. AAAS Selected Symposium 85. Westview Press, Boulder, Colorado, p. 75-95

Paffenhöfer, G.-A., Wester, B. T., Nicholas, W. D. (1984). Zooplankton abundance in relation to state and type of intrusions onto the southeastern United States shelf during summer. J. mar Res. 42: 995-1017

Piontkovskii, S. A., Petipa, T S. (1976). Quantitative description of the behavior of the copepod Acartia clausi during feeding on algae. Biol. Morya, Vadiv. 34: 49-56 (Russian), 40-46 (Engl. Translation)
Price, H. J., Paffenhöfer, G.-A. (1986). Effects of concentration on the feeding of a marine copepod in algal monocultures and mixtures. J. Plankton Res. 8: 119-128

Price, H. J., Paffenhöfer, G.-A., Strickler, J. R. (1983). Modes of cell capture in calanoid copepods. Limnol. Oceanogr. 28: 116-123

Raymont, J. E. G. (1980). Plankton and productivity in the oceans, Vol. 1, Phytoplankton, 2nd edn. Pergamon Press, New York

Reeve, M. R., Walter, M. A. (1977). Observations on the existence of lower threshold and upper critical food concentrations for the copepod Acartia tonsa Dana. J. exp. mar. Biol. Ecol. 29: 211-221

Riley, G. A. (1967). The plankton of estuaries. In: Lauff, G. H. (ed.) Estuaries, Publs Am. Ass. Advmt Sci. 83, Washington, D.C., p. 316-326

Rosenberg, G. (1980). Filmed observations of filter feeding in the marine planktonic copepod Acartia clausi. Limnol. Oceanogr. 25: 738-742

Schnack, S. B. (1982). The structure of mouth parts of copepods in Kiel Bay. Ber. dt. wiss. Kommn Meeresforsch. 29: 89-101

Sherr, E. H., Sherr, B F., Fallon, R. D., Newell, S. Y. (1986). Small, aloricate ciliates as a major component of the marine heterotrophic nanoplankton. Limnol. Oceanogr. 31: $177-183$

Stearns, D. E. (1986). Copepod grazing behavior in simulated natural light and its relation to nocturnal feeding. Mar. Ecol. Prog. Ser 30:65-76

Stickney., R. R., Knowles, S. C. (1975). Summer zooplankton distribution in a Georgia estuary. Mar. Biol. 33: 147-154

Strickler, J. R. (1984). Sticky water: a selective force in copepod evolution. In: Meyers, D. G., Strickler, J. R. (eds.) Trophic interactions within aquatic ecosystems. AAAS Symposium 85. Westview Press, Boulder, Colorado, p. $187-239$

Strickler, J. R. (1985). Feeding currents in calanoid copepods: two new hypotheses. In: Laverack, M. S. (ed.) Symposium of the Society for Experimental Biology, No. 38. Physiological adaptations of marine animals. The Company of Biologists Limited, Cambridge, p. 459-485 